\title{
Determination of the Calcination Procedure Required to Activate Edda Clay for Optimal Leaching of Alumina
}

\author{
Udochukwu Mark*, Charles Nwachukwu Anyakwo, Okechukwu Onyebuchi Onyemaobi, \\ Chijioke Samson Nwobodo
}

Department of Materials and Metallurgical Engineering, Federal University of Technology, Owerri, Nigeria

Email: *udochukwu.mark@futo.edu.ng

How to cite this paper: Mark, U., Anyakwo, C.N., Onyemaobi, O.O. and Nwobodo, C.S. (2019) Determination of the Calcination Procedure Required to Activate Edda Clay for Optimal Leaching of Alumina. Journal of Minerals and Materials Characterization and Engineering, 7, 49-63. https://doi.org/10.4236/jmmce.2019.72004

Received: December 14, 2018 Accepted: February 26, 2019

Published: March 1, 2019

Copyright $\odot 2019$ by author(s) and Scientific Research Publishing Inc. This work is licensed under the Creative Commons Attribution International License (CC BY 4.0).

http://creativecommons.org/licenses/by/4.0/

\begin{abstract}
Nigeria is the highest consumer of aluminium in Africa but lacks bauxite deposits. The replacement of bauxite alumina with other alumina bearing resources (clays in particular) has been proposed. The present study investigated the thermal treatment required to activate Edda clay from southeastern Nigeria for optimal leaching of alumina. The clay is composed mainly of kaolinite and quartz, assaying $24.65 \% \mathrm{Al}_{2} \mathrm{O}_{3}$ and $52.81 \% \mathrm{SiO}_{2}$. Thermal activation of the clay prior to leaching transformed the crystalline kaolinite mineral to an amorphous phase (metakaolinite) in which the alumina became soluble. Clay samples passing $300 \mu \mathrm{m}$ sieve were calcined at temperatures of $500^{\circ} \mathrm{C}$, $600^{\circ} \mathrm{C}, 700^{\circ} \mathrm{C}, 800^{\circ} \mathrm{C}$, and $900^{\circ} \mathrm{C}$ at holding times of 30,60 , and 90 minutes in each case. The uncalcined clay and sample heated at $1000^{\circ} \mathrm{C}$ (for 60 minutes) were used in the control experiments. Leaching of alumina from the resulting clay calcines was done in $1 \mathrm{M}$ hydrochloric acid solution at room temperature using a solid/liquid ratio of $0.02 \mathrm{~g} / \mathrm{ml}$ and shaking speed of $100 \mathrm{rpm}$. The solubility data based on the percentage of $\mathrm{Al}$ ions taken into leach solution showed that the sample calcined at $700^{\circ} \mathrm{C}$ (for 60 minutes) responded to leaching better than other samples. Samples calcined for 60 minutes at all temperatures studied were found to respond more than those held for 30 or 90 minutes. Studies on the activation energy of leaching revealed that calcines produced at $700^{\circ} \mathrm{C}$ (for 60 minutes) had both the highest leaching response (49.96\% after 1 hour at leaching temperature of $100^{\circ} \mathrm{C}$ ) and the lowest activation energy of $24.47 \mathrm{~kJ} / \mathrm{mol}$. It is concluded therefore that Edda kaolinite clay should be thermally activated for alumina yield by heating up to $700^{\circ} \mathrm{C}$ and holding for 60 minutes. The clay deposit is therefore a potential alternative resource for alumina production.
\end{abstract}




\section{Keywords}

Edda Clay, Bauxite, Kaolinite, Alumina, Calcination, Thermal Activation, Leaching

\section{Introduction}

The feedstock required to produce the metal aluminium in the Hall-Héroult process is alumina $\left(\mathrm{Al}_{2} \mathrm{O}_{3}\right)$, which is normally refined from bauxite [1]-[6]. About 90 percent of bauxite-based alumina produced worldwide is consumed in the manufacture of aluminium. The remaining 10 percent is used in paint production and ceramics mainly as abrasives and refractories [7] [8] [9] [10]. Bauxite resources are unevenly distributed around the world. Of about 55 billion tonnes reserves, West Africa has the highest share of $32 \%$, and the commodity is sold at locally unfavourable internationally competitive prices [10] [11] [12] [13] [14]. Bauxite deposits are found in Guinea, Sierra Leone, Ghana, Mali, Cameroon, and Gabon, which are all neighbouring countries to Nigeria [11] [13] [15]. However, no such deposits have been discovered in Nigeria [13] [16]. Only minor occurrences with low concentrations of bauxite minerals are reported from some regions like Ekiti province [17] [18] [19], the Jos Plateau [11], and the Mambilla Plateau west of Cameroon [11] [13] [20].

Despite the scarcity of bauxite in Nigeria, the demand for and consumption of aluminium in the country is the highest in the sub-region [14] [16]. An aluminium smelter plant established at Ikot-Abasi was shut down mainly due to inability to economically meet the bauxite/alumina importation demands of the plant [16] [21]. It is therefore pertinent that methods for producing alumina from nonbauxite alumina/aluminium bearing raw materials must be developed. The kaolinitic clays are aluminous raw materials and are well distributed on a large scale in Nigeria [12] [13] [20] [22].

Kaolinite is structurally composed of sheets of silica tetrahedral layer $\left(\mathrm{Si}_{2} \mathrm{O}_{5}\right)^{2-}$ and aluminium octahedral layer $\mathrm{Al}_{2}(\mathrm{OH})_{4}^{2+}$ [23] [24]. Thus, the structural formula of kaolinite can be written as $\mathrm{Al}_{2}(\mathrm{OH})_{4} \cdot\left(\mathrm{Si}_{2} \mathrm{O}_{5}\right)$ or $\mathrm{Al}_{2} \mathrm{O}_{3} \cdot 2 \mathrm{SiO}_{2} \cdot 2 \mathrm{H}_{2} \mathrm{O}$ in terms of oxides. Therefore, pure kaolinite has the theoretical composition of $46.54 \% \mathrm{SiO}_{2}, 39.50 \% \mathrm{Al}_{2} \mathrm{O}_{3}$, and $13.96 \% \mathrm{H}_{2} \mathrm{O}$ (equivalent to loss on ignition or LOI). This makes kaolinite the clay mineral with the highest content of alumina [25] [26]. Kaolinite clays are therefore potential sources of alumina where bauxite is scarce or depleted. In view of Nigeria's situation, namely, the scarcity of proven bauxite deposits and the abundance and widespread distribution of proven clay (aluminosilicate mineral) deposits; extraction of alumina from kaolinite clays is a welcome venture [27].

However, the alumina content of kaolinite (and other clay minerals) is chemically locked up in the clay structure; and becomes extractable or leachable after proper thermal treatment or activation [28]. The characteristic transformations 
which occur in clay materials as they are heated are illustrated in Figure 1 [29]. Four ranges of temperature are important, namely: the drying range or free-water dehydration range $\left(50^{\circ} \mathrm{C}-120^{\circ} \mathrm{C}\right)$; the clay stability range $\left(120^{\circ} \mathrm{C}-600^{\circ} \mathrm{C}\right)$; the anhydrous clay range $\left(600^{\circ} \mathrm{C}-900^{\circ} \mathrm{C}\right)$; and the recrystallization range (above $900^{\circ} \mathrm{C}$ ). As they are heated, clays undergo drying (loss of physical moisture between $50^{\circ} \mathrm{C}-120^{\circ} \mathrm{C}$ ), dehydration (further loss of physically held moisture between $120^{\circ} \mathrm{C}-550^{\circ} \mathrm{C}$ ), and de-hydroxylation (loss of chemically combined or constitutional water above $550^{\circ} \mathrm{C}$ ); accompanied by weight loss, volume changes and phase transformations [29] [30] [31]. The sequence of reactions of kaolinite heated above $600^{\circ} \mathrm{C}$ is outlined below [28] [32]:

$$
\begin{aligned}
& \underbrace{\mathrm{Al}_{2} \mathrm{O}_{3} \cdot 2 \mathrm{SiO}_{2} \cdot 2 \mathrm{H}_{2} \mathrm{O}}_{\text {Kaolin }} \longrightarrow \underset{\begin{array}{c}
\text { Dehydration } \\
\text { above } 600^{\circ} \mathrm{C}
\end{array}}{\longrightarrow} \underbrace{\mathrm{Al}_{2} \mathrm{O}_{3} \cdot 2 \mathrm{SiO}_{2}}_{\text {Metakaolinite }}+\underbrace{2 \mathrm{H}_{2} \mathrm{O}}_{\begin{array}{c}
\text { Constitutional } \\
\text { Water Removed }
\end{array}} \\
& \underbrace{4\left(\mathrm{Al}_{2} \mathrm{O}_{3} \cdot 2 \mathrm{SiO}_{2}\right)}_{\text {Metakaolinite }}-\underset{950^{\circ} \mathrm{C}-980^{\circ} \mathrm{C}}{\longrightarrow} \underbrace{3 \mathrm{Al}_{2} \mathrm{O}_{3} \cdot 2 \mathrm{SiO}_{2}}_{\text {Primary Mullite }}+\underbrace{\gamma-\mathrm{Al}_{2} \mathrm{O}_{3}}_{\text {Gamma-Alumina(fcc) }}+\underbrace{6 \mathrm{SiO}_{2}}_{\begin{array}{c}
\text { Amorphous } \\
\text { Silica }
\end{array}} \\
& \underbrace{\gamma-3 \mathrm{Al}_{2} \mathrm{O}_{3}}_{\text {Gamma-Alumina(fcc) }}+\underbrace{3 \mathrm{SiO}_{2}}_{\begin{array}{c}
\text { Amorphous } \\
\text { Silica }
\end{array}} \longrightarrow \frac{1000^{\circ} \mathrm{C}-1400^{\circ} \mathrm{C}}{\longrightarrow} \underbrace{3 \mathrm{Al}_{2} \mathrm{O}_{3} \cdot 2 \mathrm{SiO}_{2}}_{\text {Secondary Mullite }}+\underbrace{\mathrm{SiO}_{2}}_{\text {Tridymite }} \\
& \underbrace{3 \mathrm{Al}_{2} \mathrm{O}_{3} \cdot 2 \mathrm{SiO}_{2}}_{\text {Secondary Mullite }}+\underbrace{\mathrm{SiO}_{2}}_{\text {Tridymite }} \longrightarrow \frac{1400^{\circ} \mathrm{C}-1580^{\circ} \mathrm{C}}{\longrightarrow} \underbrace{3 \mathrm{Al}_{2} \mathrm{O}_{3} \cdot 2 \mathrm{SiO}_{2}}_{\text {Mullite }}+\underbrace{\mathrm{SiO}_{2}}_{\text {Cristobalite }}
\end{aligned}
$$

The goal of heating a clay before leaching is to produce metakaolinite $\left(\mathrm{Al}_{2} \mathrm{O}_{3} \cdot 2 \mathrm{SiO}_{2}\right)$, an anhydrous amorphous phase in which the alumina is soluble. Since clays from different localities vary considerably in mineralogy, chemical composition, degree of crystallinity and purity [28] [33]; the thermal treatment for activating or transforming each clay to amorphous phase must be evaluated specifically. The current investigation is concerned with determining the calcination procedure required to produce an anhydrous amorphous phase or metakaolinite from Edda clay found in south-eastern Nigeria. The amenability of the clay calcines produced using different thermal treatments to alumina leaching in hydrochloric acid solution was studied.

\section{Materials and Methods}

The raw clay sample was obtained from Edda clay deposit (Lat. $5^{\circ} 57^{\prime} 54 " \mathrm{~N}$, Long. $\left.7^{\circ} 51^{\prime} 56^{\prime \prime} \mathrm{E}\right)$ in Afikpo-South LGA of Ebonyi state, Nigeria. The clay was sun-dried, crushed and ground. The ground clay sample was placed on a $300 \mu \mathrm{m}$ ASTM sieve and shaken for 5 minutes. The oversize was further ground and sieved on

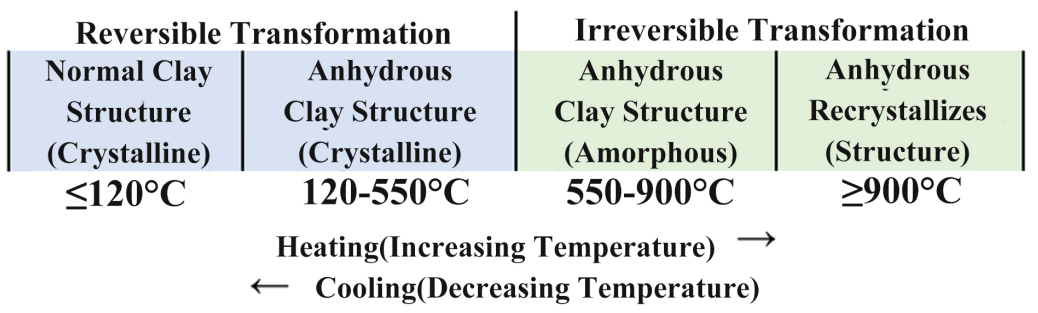

Figure 1. Effect of temperature on the physical state of clay minerals ([29], p.174). 
the same sieve. The procedure was repeated until the entire clay sample passed through the $300 \mu \mathrm{m}$ sieve (50 standard Tyler mesh).

\subsection{Mineralogical and Chemical Analyses}

The mineralogical and chemical compositions of the sieved clay were obtained by x-ray diffraction (Pananalytical XRD, Empyrean model) and atomic absorption spectrophotometery (Buckscientific AAS, model 210 VGP). The optimal clay calcine (which responded most to leaching) was also analysed with XRD to determine the effect of the selected thermal treatment on the transformation of the clay. The loss on ignition (LOI) was determined by placing one gramme of dry clay sample (dried at $105^{\circ} \mathrm{C}$ for 12 hours in an oven) into a platinum crucible of known weight $\left(W_{d}\right)$. This was subsequently fired at $1000^{\circ} \mathrm{C}$ for 1 hour in a muffle furnace. At lapse of time, the crucible was brought out of the furnace and reweighed $\left(W_{f}\right)$ after cooling down to room temperature. The LOI was calculated in percentage as $\left(W_{d}-W_{f} / W_{d}\right) \times 100$.

\subsection{Thermal Treatment}

Ground and sieved clay samples passing $300 \mu \mathrm{m}$ sieve were subjected to thermal treatments in a muffle furnace at a heating rate of $15^{\circ} \mathrm{C}$ per minute up to the holding temperature $\left(500^{\circ} \mathrm{C}, 600^{\circ} \mathrm{C}, 700^{\circ} \mathrm{C}, 800^{\circ} \mathrm{C}\right.$ or $\left.900^{\circ} \mathrm{C}\right)$ and held for 30,60 or 90 minutes before furnace-cooling to room temperature. A sample of the raw or uncalcined clay and another sample heated up to $1000^{\circ} \mathrm{C}$ (and held for 60 minutes) were used for the control experiments.

\subsection{Leaching Studies}

Analytical grade $\mathrm{HCl}$ acid and pure deionized water were used to prepare the leaching reagent. 1 molar standard solution of hydrochloric acid was prepared using deionized water. This was used as the leaching reagent for the leaching studies to determine the leaching response of the various clay calcines and the controls. The leaching was done under moderate leaching conditions, i.e. hydrochloric acid concentration of $1 \mathrm{M}$, leaching temperature at ambient $\left(\sim 25^{\circ} \mathrm{C}\right)$, shaking speed of $100 \mathrm{rpm}$, and solid/liquid ratio or clay weight to acid volume ratio of $0.02 \mathrm{~g} / \mathrm{ml}$, using clay particles passing $300 \mu \mathrm{m}$ ( $-50 \mathrm{mesh})$.

The leach contact time or duration ranged from 0 to 120 minutes at intervals of 30 minutes. An orbital shaker (KOMA, model KED11) was used to shake the reaction bottles at a constant rate of $100 \mathrm{rpm}$ during the contact time (duration of leaching) to facilitate the reaction. By the end of leaching, the resulting slurry was filtered to separate undissolved materials (residue) from the filtrate (leachate or pregnant solution). The leachate was analysed for aluminium ion concentration by means of the Buckscientific AAS.

This procedure was repeated for all the clay calcines and the control samples, which were prepared at different temperatures and duration of calcination. The optimum condition for calcining the clay was determined using solubility data 
(concentration or fraction of aluminium ion solubilized).

After examination of the extent of aluminium extraction or solubilization from the clay calcines, the calcine with the best leaching response for each calcination temperature was subjected to activation energy studies by leaching them at different temperatures. This was done to establish the thermodynamic basis for their better leaching kinetics in accordance with the Arrhenius rate law (Equation (5)), in which $k$ is the leaching rate constant, $A$ is the Arrhenius frequency factor, $E_{a}$ is the activation energy for the leaching reaction, $R$ is the universal gas constant $\left(=8.314 \mathrm{~J} \cdot \mathrm{mol}^{-1} \cdot \mathrm{K}^{-1}\right)$, and $T$ is the leaching temperature on the absolute scale.

$$
k=A e^{-\left(\frac{E_{a}}{R T}\right)} \text { or } \ln k=-\left(\frac{E_{a}}{R}\right) \cdot \frac{1}{T}+\ln A
$$

Consequently, samples held for 60 minutes at different temperatures of calcination were leached in $1 \mathrm{M} \mathrm{HCl}$ for 60 minutes at $25^{\circ} \mathrm{C}, 50^{\circ} \mathrm{C}, 75^{\circ} \mathrm{C}$ and $100^{\circ} \mathrm{C}$ by means of a constant temperature water bath. All other variables such as clay particle size, shaking speed, and solid/liquid ratio were kept constant at less than $300 \mu \mathrm{m}$ (-50 mesh), $100 \mathrm{rpm}$ and $0.02 \mathrm{~g} / \mathrm{ml}$, respectively. The natural logarithm of rate constants $(\ln k)$ as deduced from the solubility data (based on second-order reaction kinetics which appeared to fit the data) and the reciprocal of absolute temperature $\left(\frac{1}{T}\right)$ were used for Arrhenius plots to determine the activation energy $\left(E_{a}\right)$ in the case of each clay calcine [34].

\section{Results and Discussion}

\subsection{Type and Composition of Clay}

The x-ray diffraction pattern of the raw clay is shown in Figure 2 with the peaks for the constituent mineral phases clearly identified. As shown, the clay is dominated by kaolinite mineral with quartz (free silica) and haematite as associated impurities. Figure 3 is the XRD pattern for the optimal clay calcine showing the disappearance of the sharp kaolinite peaks seen in Figure 2. The disappearance of the kaolinite peaks is an indication of the appearance of an amorphous phase (i.e. metakaolinite) due to thermal transformation of the clay [28] [33]. It is this

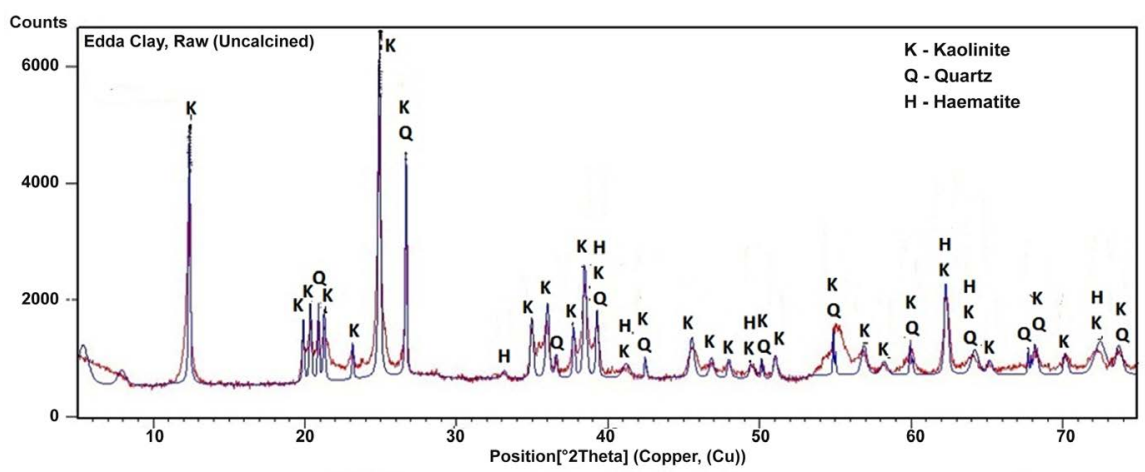

Figure 2. XRD pattern of uncalcined Edda clay. 


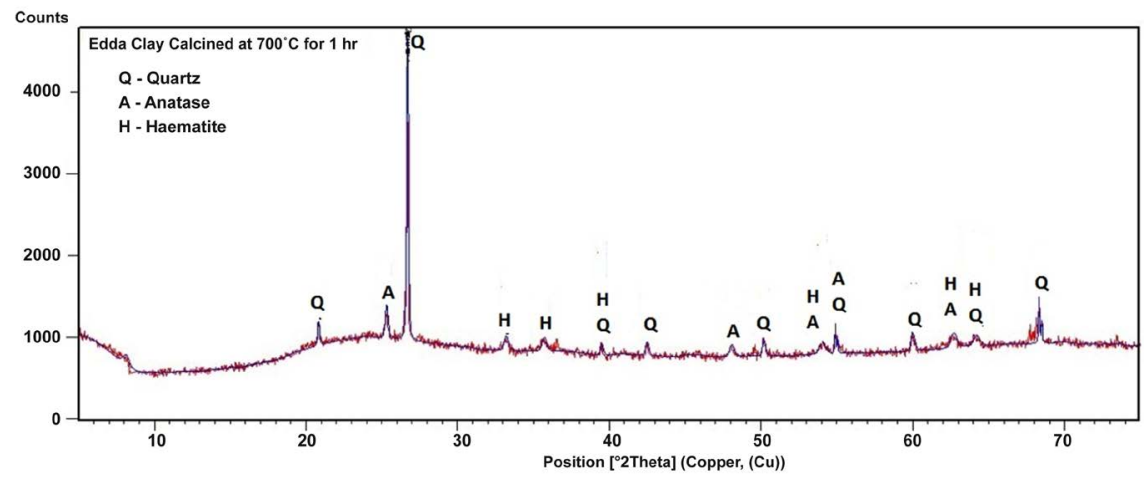

Figure 3. XRD pattern of Edda clay calcined at $700^{\circ} \mathrm{C}$ for 1 hour.

amorphous metakaolinite $\left(\mathrm{Al}_{2} \mathrm{O}_{3} \cdot 2 \mathrm{SiO}_{2}\right)$ that releases its alumina $\left(\mathrm{Al}_{2} \mathrm{O}_{3}\right)$ for dissolution making the clay respond to acid leaching. This behaviour, known as thermal activation, is due to proper thermal treatment and transformation of the clay [28].

The chemical composition is shown in Table 1 . The alumina content of about $24.65 \%$ is considered good enough for hydrometallurgical treatment of the clay as a source of alumina [6] [35] [36]. However, the presence of iron oxide up to $3 \%$ means that purification of the clay will be necessary before activation and leaching.

\subsection{Mechanism of Alumina Dissolution}

The extent of dissolution of alumina from the clay is given by the concentration of $\mathrm{Al}$ ions detected in leach solutions after leaching the various clay calcines. This was expressed in percentage or as a fraction. The fraction of $\mathrm{Al}$ ions $\left(X_{\mathrm{Al}}\right)$ leached out of the clay into the solution was given as:

$$
X_{\mathrm{Al}}=\frac{\text { concentration of } \mathrm{Al} \text { ions in the solution }}{\text { concentration of } \mathrm{Al} \text { ions in the original clay sample }}
$$

Multiplication of Equation (6) by 100 gives the percentage of $\mathrm{Al}$ ions (\% $\mathrm{Al})$ leached out of the clay. The presence of $\mathrm{Al}^{3+}$ ions in the leach solutions shows that a dissolution reaction occurred between the alumina in the clay calcine and the leaching reagent. It is proposed that hydrochloric acid ionized in water to produce protons or hydrogen ions $\left(\mathrm{H}^{+}\right)$in the hydrated form known as hydronium $\left(\mathrm{H}_{3} \mathrm{O}^{+}\right)$in accordance with reaction (7) [37].

$$
\mathrm{HCl}+\mathrm{H}_{2} \mathrm{O} \rightleftharpoons \mathrm{H}_{3} \mathrm{O}_{\mathrm{aq}}^{+}+\mathrm{Cl}_{\mathrm{aq}}^{-} \text {or } \mathrm{HCl}_{\mathrm{aq}} \rightleftharpoons \mathrm{H}_{\mathrm{aq}}^{+}+\mathrm{Cl}_{\mathrm{aq}}^{-}
$$

The dissolution of alumina $\left(\mathrm{Al}_{2} \mathrm{O}_{3}\right)$ from the clay is therefore the result of chemical interaction between hydrogen ions $\left(\mathrm{H}^{+}\right)$and aluminium atoms of the alumina according to reaction (8):

$$
\mathrm{Al}_{2} \mathrm{O}_{3} \cdot 2 \mathrm{SiO}_{2}+6\left(\mathrm{H}^{+} \mathrm{Cl}^{-}\right) \rightarrow\left(2 \mathrm{Al}^{3+} 6 \mathrm{Cl}^{-}\right)+3 \mathrm{H}_{2} \mathrm{O}+2 \mathrm{SiO}_{2}
$$

\subsection{Effect of Calcination Temperature}

The results of leaching showed that thermal treatment (particularly, calcination 
Table 1. Chemical composition of Edda clay.

\begin{tabular}{ccccccccc}
\hline \multicolumn{7}{c}{ Chemical Composition (\%) } \\
\hline $\mathrm{SiO}_{2}$ & $\mathrm{Al}_{2} \mathrm{O}_{3}$ & $\mathrm{Fe}_{2} \mathrm{O}_{3}$ & $\mathrm{TiO}_{2}$ & $\mathrm{CaO}$ & $\mathrm{MgO}$ & $\mathrm{Na}_{2} \mathrm{O}$ & $\mathrm{K}_{2} \mathrm{O}$ & LOI \\
\hline 52.81 & 24.65 & 3.05 & 0.76 & 1.23 & 0.92 & 1.82 & 1.04 & 11.8 \\
\hline
\end{tabular}

temperature) has significant effect on the amount of $\mathrm{Al}^{3+}$ ions taken into solution. The effect of calcination temperatures at different durations of heating (30, 60 or 90 minutes) is illustrated in Figures 4-6. As shown, leaching response is lowest for the uncalcined clay sample (control $1, \sim 25^{\circ} \mathrm{C}$ ) followed by that calcined at $1000^{\circ} \mathrm{C}$ (control 2) at all three durations of calcination. This means that the ability of the acid $(1 \mathrm{M} \mathrm{HCl})$ to extract alumina from the clay (and enrich the leach solution with aluminium ions) varied as calcination temperature increased from $500^{\circ} \mathrm{C}$ to $900^{\circ} \mathrm{C}$. However, at $1000^{\circ} \mathrm{C}$ (control 2), the ability of the acid to attack the clay and remove alumina dropped drastically. Under 30, 60 and 90 minutes holding times (Figures 4-6); the peak leaching response occurred in the case of samples calcined at $700^{\circ} \mathrm{C}$. The response of Edda clay to leaching by acid attack increased and dropped between $500^{\circ} \mathrm{C}$ and $900^{\circ} \mathrm{C}$; reaching its peak at $700^{\circ} \mathrm{C}$. This behaviour is probably due to the transformation of the clay from its room temperature crystalline form (kaolinitic) to various degrees of amorphous state and back to high temperature crystalline form at $1000^{\circ} \mathrm{C}$ and beyond, as the clay steadily lost physically combined water (through drying and dehydration) and chemically combined water (de-hydroxylation) as temperature increased. In other words, the clay transformed completely to an amorphous phase (metakaolinite) when it was heated to $700^{\circ} \mathrm{C}$, while crystallinity or various degrees of crystallinity existed in the clay below and above $700^{\circ} \mathrm{C}$.

\subsection{Effect of Holding Time}

Another observation is that samples held for 60 minutes in the furnace responded better on leaching than those held for 30 or 90 minutes at all calcination temperatures investigated (Figure 7). The ability of the acid to attack alumina in the clay and remove aluminium was low at 30 minutes holding time, reached peak value at 60 minutes holding time, and declined again when holding time was extended to 90 minutes at all temperatures studied $\left(500^{\circ} \mathrm{C}, 600^{\circ} \mathrm{C}\right.$, $700^{\circ} \mathrm{C}, 800^{\circ} \mathrm{C}$, and $900^{\circ} \mathrm{C}$ ). This observation could be because the transformation of the clay to amorphous (non-crystalline) state was just beginning at 30 minutes duration; the transformation to amorphous metakaolinite reached advanced stage at 60 minutes but holding up to 90 minutes resulted to the reappearance of some crystallinity. Prolonged heating can therefore make the silica and alumina contents of clay to react, resulting in reduction of solubility. Prolonged heating may also bring about the sintering of particles or phases leading to reduction in leaching response [38]. It can be concluded therefore that 60 minutes or 1 hour is the optimum calcination holding time for thermal activation of Edda clay to respond maximally to leaching in acid. 


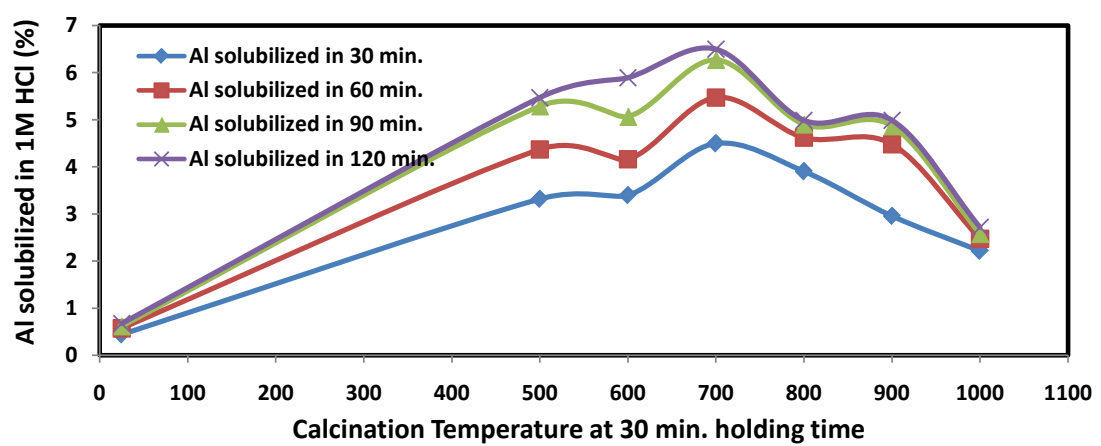

Figure 4. Effect of calcination temperature at 30 minutes holding time on the solubilization of $\mathrm{Al}$ from Edda clay leached at room temperature.

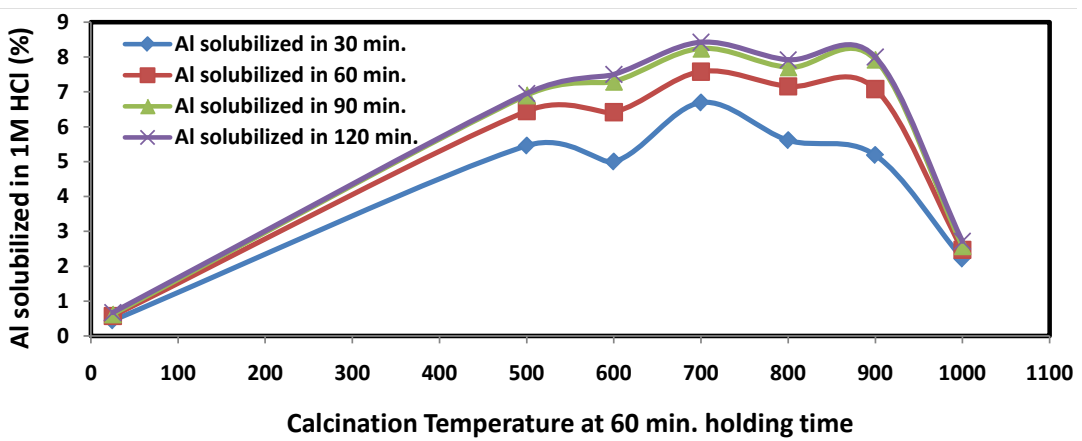

Figure 5. Effect of calcination temperature at 60 minutes holding time on the solubilization of $\mathrm{Al}$ from Edda clay leached at room temperature.

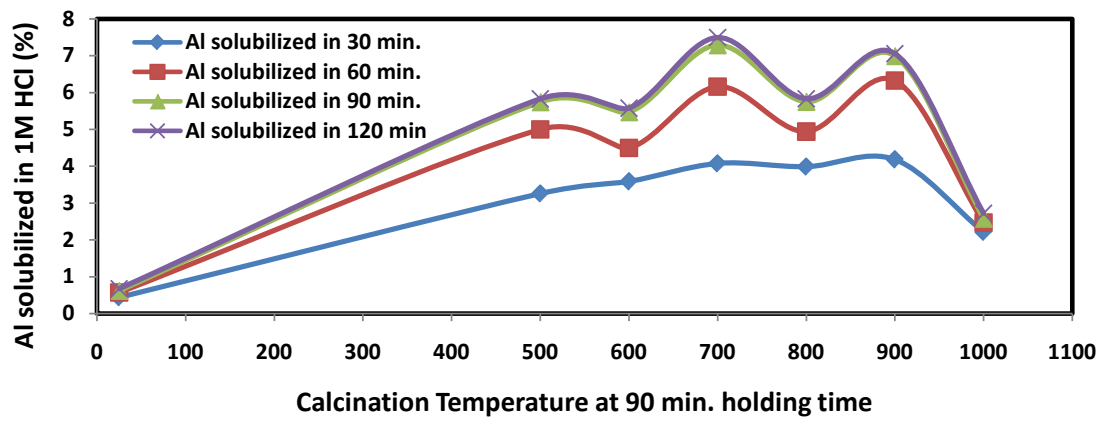

Figure 6. Effect of calcination temperature at 90 minutes holding time on the solubilization of $\mathrm{Al}$ from Edda clay leached at room temperature.

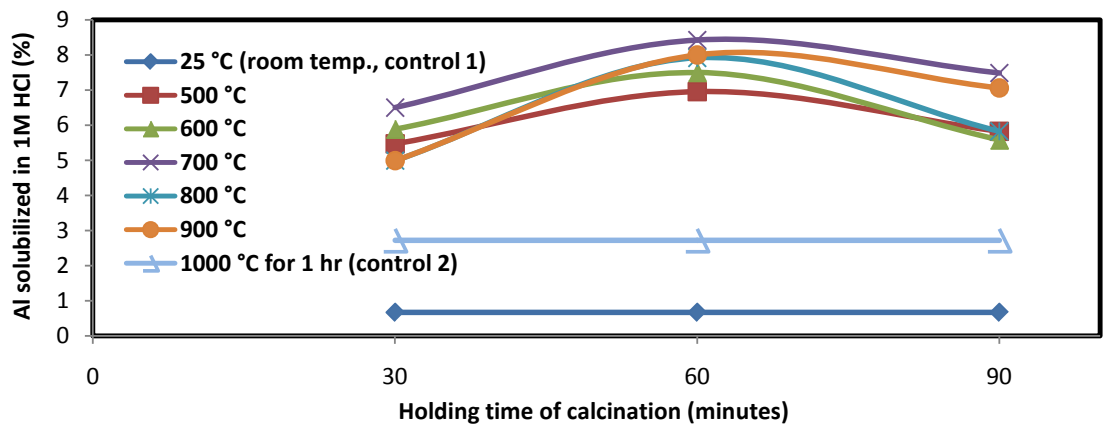

Figure 7. Effect of calcination duration (holding time) on solubilization of Al from Edda clay leached at room temperature. 
These observations are in conformity with XRD patterns shown in Figure 2 and Figure 3 for the raw and optimally calcined clays. Thermal treatment therefore broke down the clay structure by removing the $\mathrm{OH}$ water (chemically combined) holding the network of silica tetrahedra and alumina octahedra, thus rendering the alumina acid-soluble. At sufficiently high temperatures or for prolonged heating durations, the silica and alumina recrystallized to form a crystalline and insoluble phase (e.g. mullite). It can be concluded therefore that heating to $700^{\circ} \mathrm{C}$ and holding for 60 minutes is the optimum calcination temperature and duration for thermally activating Edda clay to respond to acid leaching.

\subsection{Effect of Leaching Temperature}

As observed previously, clay calcines produced by holding for 60 minutes in the furnace (at all calcination temperatures studied) responded to leaching better than those held for 30 or 90 minutes. The effect of leaching temperature on the leaching response of calcines produced under 60 minutes duration of calcination is shown in Figure 8. It is shown that at all calcination temperatures investigated, leaching response increased as leaching temperature increased. In the case of the optimal calcine $\left(700^{\circ} \mathrm{C}\right.$ held for 60 minutes), the amounts of aluminium solubilised after leach contact time of 1 hour in $1 \mathrm{M} \mathrm{HCl}$ were $12.34 \%, 21.54 \%$, $36.68 \%$, and $49.96 \%$ for leaching temperatures of $25^{\circ} \mathrm{C}, 50^{\circ} \mathrm{C}, 75^{\circ} \mathrm{C}$, and $100^{\circ} \mathrm{C}$, respectively. It can be concluded that leaching temperature has a significant effect on the rate of alumina dissolution from the clay. This is because high temperatures enhance diffusion or mobility and hence collision frequency of reacting species in addition to providing extra thermal energy for overcoming the energy barrier or activation energy for the process. Similar observations have been made in literature [38] [39] [40]. Figure 8 also illustrates the effect of thermal activation on leaching of clay calcines produced at different temperatures. For example, the $\mathrm{Al}$ extracted within 1 hour of leaching in $1 \mathrm{M} \mathrm{HCl}$ at $100^{\circ} \mathrm{C}$ increased from $7.43 \%$ (uncalcined clay) to $49.96 \%$ (optimal calcine, $700^{\circ} \mathrm{C}$ )

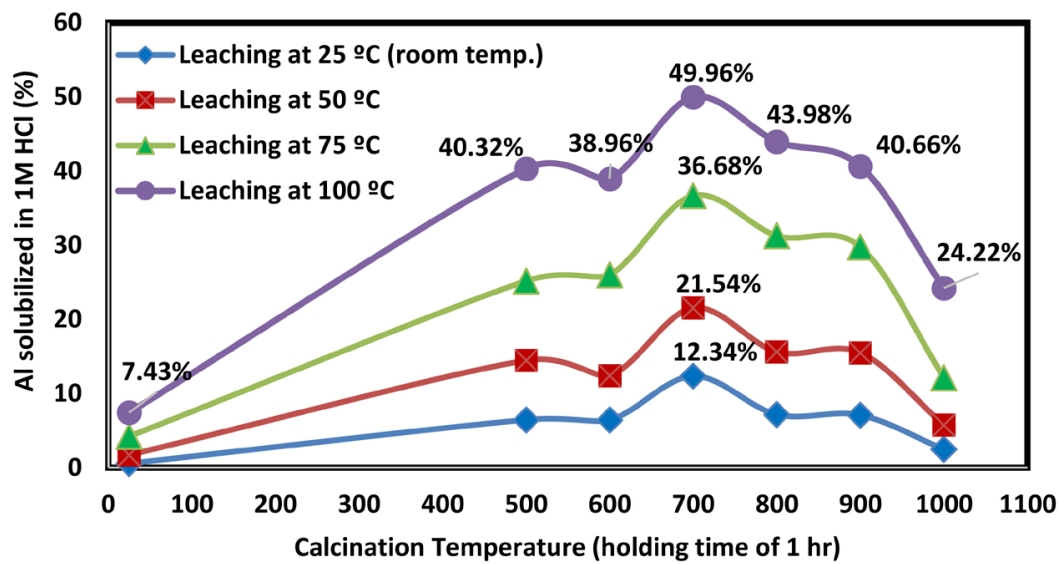

Figure 8. Effect of leaching temperature on the leaching response of selected Edda clay calcines within leach contact time of 60 minutes. 
followed by a steady decline in $\mathrm{Al}$ extraction to $24.22 \%$ (for calcine produced at $1000^{\circ} \mathrm{C}$ ). Similar trends were also observed at leaching temperatures of $25^{\circ} \mathrm{C}$, $50^{\circ} \mathrm{C}$ and $75^{\circ} \mathrm{C}$. This can be explained based on solid phase changes or transformations in the clay brought about by thermal treatment [38] [39] [40] [41].

\subsection{Thermal Treatment and Activation Energy}

The activation energy of leaching was found to depend on the thermal treatment given to the clay. Thermal treatment itself determined whether the clay is in its hydrated crystalline form, anhydrous amorphous form, or anhydrous crystalline form, and the degree of crystallinity or otherwise. Figure 9 shows plots of $\ln k$ versus $1 / T$ for samples calcined at different temperatures under 60 minutes holding time and leached at different leaching temperatures, i.e. $25^{\circ} \mathrm{C}(298 \mathrm{~K})$, $50^{\circ} \mathrm{C}(323 \mathrm{~K}), 75^{\circ} \mathrm{C}(348 \mathrm{~K})$ and $100^{\circ} \mathrm{C}(373 \mathrm{~K})$. The activation energies of leaching for calcines produced under different thermal treatments (calcination temperatures) are also included in the Arrhenius plots of Figure 9. It is seen that the uncalcined clay required the highest activation energy $(32.82 \mathrm{~kJ} / \mathrm{mol})$ followed closely by the calcine produced at $1000^{\circ} \mathrm{C}(31.05 \mathrm{~kJ} / \mathrm{mol})$. Other calcines had activation energies varying between these two extremes, with the lowest occurring in the case of calcine produced at $700^{\circ} \mathrm{C}(24.47 \mathrm{~kJ} / \mathrm{mol})$. Since in this case, activation energy represents the energy barrier that must be overcome to leach alumina from the clay; it is expected that the calcine produced at $700^{\circ} \mathrm{C}$ would respond most to leaching compared to the rest. Similarly, the uncalcined clay which is in the fully hydrated crystalline form would be the least leached followed by the fully anhydrous crystalline form produced at $1000^{\circ} \mathrm{C}[28]$ [38] [39].

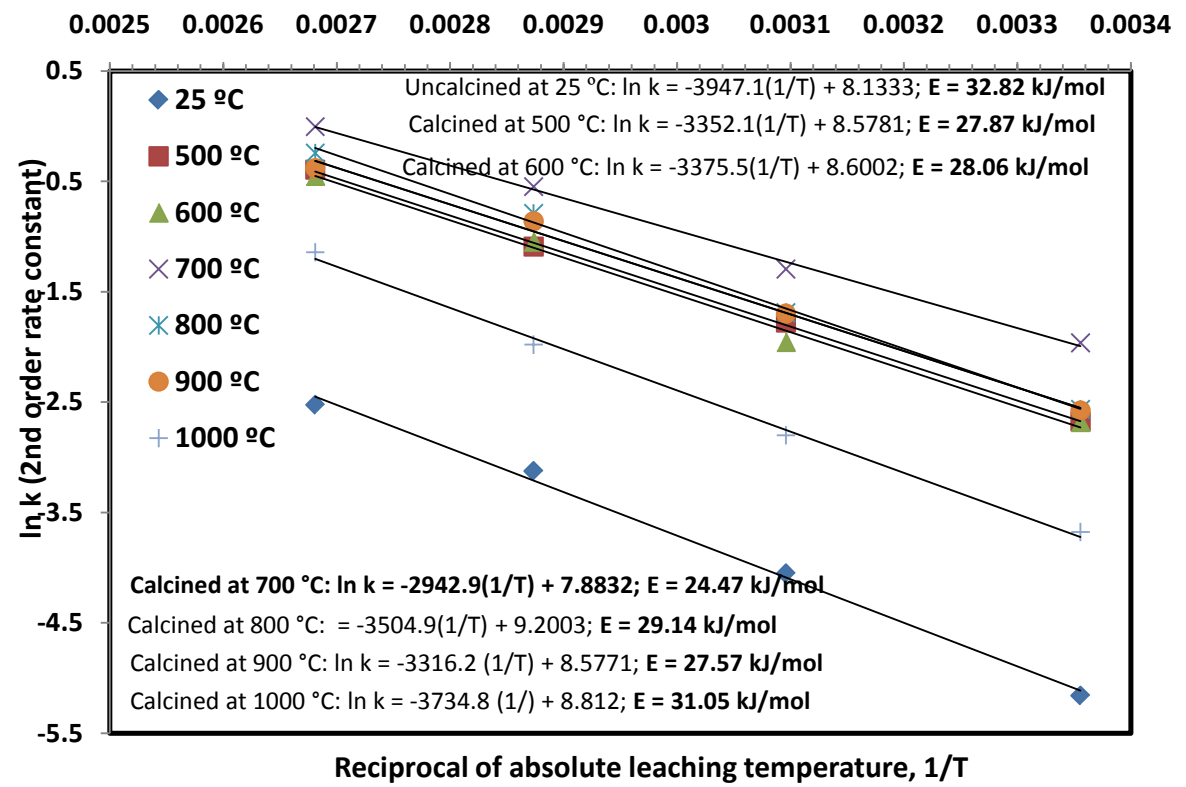

Figure 9. Arrhenius plots for the leaching of Edda clay calcined at various temperatures and leached in $1 \mathrm{M} \mathrm{HCl}$ at 198, 323, 348 and 373 Kelvin. 


\subsection{Effect of Activation Energy on Leaching}

The preceding discussion has shown that activation energy of leaching depended on the thermal treatment given to the clay. Figure 10 shows the effect of calcination temperature (thermal treatment) on activation energy of leaching and by extension, on the leaching response. By comparing Figure 8 and Figure 9 in Figure 10, the activation energies for the various thermal treatments (calcination temperatures) are shown with the $\% \mathrm{Al}$ solubilized when leaching was done at $100^{\circ} \mathrm{C}$. Low activation energies were obtained in the case of the clay calcines that responded well to leaching i.e. those with high level of $\mathrm{Al}$ extraction. This implies that the optimal temperature and duration of calcination $\left(700^{\circ} \mathrm{C}\right.$ for 60 minutes) corresponded with the lowest activation energy $(24.47 \mathrm{~kJ} / \mathrm{mol})$. The lowest activation energy for leaching, as shown, corresponds with the overall best calcine for the clay considering the aluminium solubility rate of $49.96 \%$. Given that activation energy is the energy barrier that must be surmounted for a reaction to occur; the lowering of this energy means that leaching reaction is made thermodynamically or energetically easier, thus enhancing reaction rates or kinetics. This explains why clay calcine produced at $700^{\circ} \mathrm{C}$ (holding for 60 minutes) yielded the highest solubility of alumina from the clay as shown by the $\% \mathrm{Al}$ in leach solution. It was also observed that the uncalcined sample of the clay required the highest activation energy of leaching ( $32.82 \mathrm{~kJ} / \mathrm{mol})$; explaining why it was very difficult to leach alumina from such sample, as seen in its very low solubility data of $7.43 \% \mathrm{Al}$. Thus, the alumina in uncalcined or unactivated clay is locked up in the clay chemistry, responding very sluggishly to acid attack. Similarly, clay sample calcined at $1000^{\circ} \mathrm{C}$ for 60 minutes recorded the next highest activation energy $(31.05 \mathrm{~kJ} / \mathrm{mol})$ and low solubility $(24.22 \% \mathrm{Al})$. Leaching of alumina was also difficult in this case because at $1000^{\circ} \mathrm{C}$, formation of crystalline phases had commenced. Thus, the alumina is again locked up in the mullite network, making it difficult for acid attack. Similar findings were reported in previous works [38] [39] [40] [41].

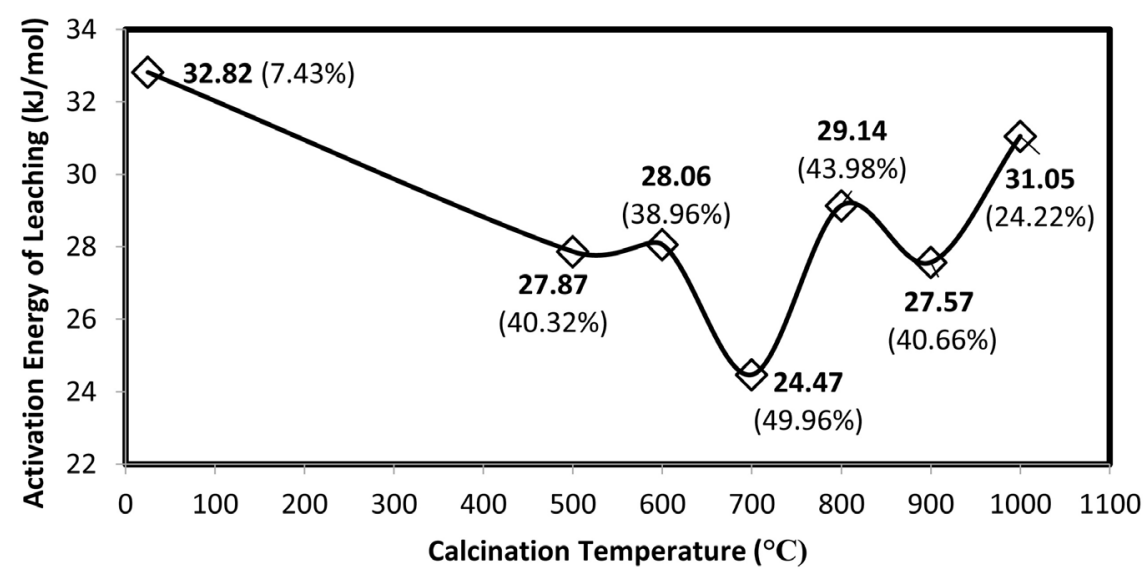

Figure 10. Effect of calcination temperature on activation energy of leaching for Edda clay leached in $1 \mathrm{M} \mathrm{HCl}$ for 60 minutes contact time. 
As shown in Figure 10, values of activation energy varied between the extremes of the high values reported for the uncalcined clay (at $\sim 25^{\circ} \mathrm{C}$ ) and those for samples calcined at $1000^{\circ} \mathrm{C}$; reaching the lowest value of $24.47 \mathrm{~kJ} / \mathrm{mol}$ at $700^{\circ} \mathrm{C}$. This means that the clay transformed completely to an anhydrous amorphous form at $700^{\circ} \mathrm{C}$. This corresponds to the temperature at which the clay was thermally activated for maximum leaching response because of the presence of metakaolinite [28]. The alumina in the amorphous phase is therefore more soluble than that in the crystalline or semi-crystalline phases that existed below and above $700^{\circ} \mathrm{C}$.

\section{Conclusions}

The effect of thermal treatment on the response of Edda kaolinite clay to acid leaching was investigated. Different thermal treatments produced different degrees of leaching response from the clay. X-ray diffraction studies confirmed that the optimal leaching response corresponded with the thermal treatment that transformed the clay to an amorphous phase or metakaolinite. The clay was transformed from its low-temperature crystalline form (below $600^{\circ} \mathrm{C}$ ) to an amorphous form (at $700^{\circ} \mathrm{C}$ ) and then back to high-temperature crystalline phases above $900^{\circ} \mathrm{C}$. Prolonged heating (above 90 minutes) under isothermal conditions also caused the appearance of crystalline phases and loss of solubility. Best results were achieved under 60 minutes heating duration at $700^{\circ} \mathrm{C}$. Thermal treatment also affected the activation energy of leaching such that high solubility (high leaching response) corresponded with low activation energy. Thus, the thermal activation of Edda clay for alumina leaching is possible and the clay can be used as an alternative resource for alumina in Nigeria where bauxite is scarce or non-existent.

Whereas the present work has established the optimal calcination conditions for Edda clay; further work is recommended to investigate the effects of the leaching variables, viz. clay particle size, acid concentration, leaching temperature, solid/liquid ratio of clay weight to acid volume, and shaking rate. This will establish the optimal leaching conditions for the clay calcine. Recovery of alumina from the leach solution is also recommended.

\section{Acknowledgements}

This work was funded through a research fellowship (REG/EST/SPMU/SP.2318) of the Federal University of Technology, Owerri. The authors would like to thank the unknown reviewers for their helpful comments and suggestions.

\section{Conflicts of Interest}

The authors declare no conflicts of interest regarding the publication of this paper.

\section{References}

[1] Hudson, K., Misra, C. and Wefers, K. (1997) Aluminium Oxide. In: Habashi, F., 
Ed., Handbook of Extractive Metallurgy, Volume II, Part 3: Light Metals, John Wiley \& Sons, Inc, New York, 1062-1068.

[2] Hudson, K., Misra, C. and Wefers, K. (1997) Bauxite, the Principal Alumina Raw Material. In: Habashi, F., Ed., Handbook of Extractive Metallurgy, Volume II, Part 3: Light, John Wiley \& Sons, Inc., New York, 1068-1072.

[3] Hudson, K., Misra, C. and Wefers, K. (1997) Other Processes for Alumina Production. In: Habashi, F., Ed., Handbook of Extractive Metallurgy, Volume II, Part 3: Light Metals, John Wiley \& Sons, Inc., New York, 1091-1094.

[4] Hudson, L.K., Misra, C., Perrotta, A.J., Wefers, K. and Williams, F.S. (2011) Aluminum Oxide. In: Elvers, B., Ed., Ullman's Encyclopedia of Industrial Chemistry, Wiley-VCH, Weiheim, 7th Edition, $40 \mathrm{p}$.

[5] Habashi, F. (1995) Bayer's Process for Alumina Production: A Historical Perspective. Bulletin of Historical Chemistry, No. 17-18, 15-19.

[6] Habashi, F. (2005) A Short History of Hydrometallurgy. Hydrometallurgy, 79, 15-22. https://doi.org/10.1016/j.hydromet.2004.01.008

[7] United States Geological Survey (USGS) (2013) Bauxite and Alumina. In: 2013 Minerals Yearbook (Advance Release). Compiled by E. Lee Bray, L.M. White \& L.D. Miller, $13 \mathrm{p}$.

[8] United States Geological Survey (USGS) (2015) Aluminium: Mineral Commodity Summaries, 30 January 2015. Compiled by E. Lee Bray, 16-17.

[9] United States Geological Survey (USGS) (2015) Bauxite and Alumina: Mineral Commodity Summaries, 30 January 2015. Compiled by E. Lee Bray, 26-27.

[10] United States Geological Survey (USGS) (2015) Bauxite and Alumina: Mineral Industry Surveys, First Quarter of 2015. Compiled by E. Lee Bray \& Linda M. Barnes, $1-5$.

[11] Schwarz, T. (1997) Distribution and Genesis of Bauxite on the Mambilla Plateau, SE Nigeria. Applied Geochemistry, 12, 119-131.

https://doi.org/10.1016/S0883-2927(96)00058-3

[12] Petters, S.W. (1993) Metallic and Nonmetallic (Industrial) Minerals. In: Adalemo, I.A. and Baba, J.M., Eds., Nigeria: Giant in the Tropics, Volume 1: A Compendium, Gabuno Publishing Ltd., Lagos, 61.

[13] Obaje, N.G. (2009) Geology and Mineral Resources of Nigeria: Lecture Notes in Earth Sciences 120. Springer, London, 52, 118-119, 183-201.

[14] Pabalkar, V.V. (1999) Nigerian Aluminium Industry: Scope and Prospects. Proceedings of the 16th Annual Conference of the Nigerian Metallurgical Society (NMS), Abuja, 3-5 November 1999, 1-7

[15] Wright, J.B., Hastings, D.A., Jones, W.B. and Williams, H.R. (1985) Geology and Mineral Resources of West Africa. George Allen \& Unwin (Publishers) Ltd., London, 35, 48-49, 87, 119, 145, 157.

[16] Okorie, B.A. (2000) The Metallurgical Industry and National Development. 2nd Annual NAMMES Conference Tagged, Owerri, 16-17 March 2000, 8 p.

[17] Malomo, S. (2011) Framework and Opportunities for Sustainable Private Sector Participation in Solid Minerals Development in Ekiti State. Ekiti State Economic Development Summit, Ado Ekiti, 15 October 2011, 15 p.

[18] Talabi, A.O., Ademilua, O.L., Ajayi, O.Z. and Ogunniyi, S.O. (2013) Preliminary Geophysical Evaluation of Orin Bauxite Deposit, Southwestern Nigeria. Journal of Emerging Trends in Engineering and Applied Sciences, 4, 432-437.

[19] Sada, M.M. (2013) Mid-Term Report for the Minerals and Metals Sector. Ministeri- 
al Platform Presented by Minister, Ministry of Mines and Steel Development (MMSD).

[20] Aliyu, A. (1996) Potentials of the Solid Minerals Industry in Nigeria. RMRDC, Abuja, 1-40, 63-83, 164-172.

[21] Adeniji, G. (2009) An Overview of Nigeria's Solid Minerals Sector. Accenture Knowledge Event, 19 January 2009, 1-10.

[22] Fejokwu, L.C. (1996) Nigeria: A Viable Black Power, Volume 2: Resources, Potentials and Challenges. Polcom Press, Lagos, 375-385.

[23] Barsoum, M.W. (2003) Fundamentals of Ceramics. 2nd Edition, IOP Publishing Ltd., Bristle, 70-74. https://doi.org/10.1887/0750309024

[24] Shackelford, J.F. (2015) Introduction to Materials Science for Engineers. 8th Edition, Pearson Higher Education, Upper Saddle River, 71-72.

[25] Attah, L.E. and Oden, M.I. (2010) Physico-Chemical Properties and Industrial Potential of Some Clay Deposits in Calabar Area, South Eastern Nigeria. Global Journal of Environmental Sciences, 9, 39-49.

[26] Velde, B. (1995) Composition and Mineralogy of Clay Minerals. In: Velde, B., Ed., Origin and Mineralogy of Clays: Clays and the Environment, Springer, Verlag, 8-29. https://doi.org/10.1007/978-3-662-12648-6_2

[27] Mark, U. and Onyemaobi, O.O. (2009) Assessment of the Industrial Potentials of Some Nigerian Kaolinitic Clay Deposits. International Research Journal in Engineering, Science and Technology, 6, 77-84.

[28] Chakraborty, A.K. (2014) Phase Transformations of Kaolinite Clay. Springer, New Delhi, 3-12, 43-47, 185-206, and 327-329.

https://doi.org/10.1007/978-81-322-1154-9

[29] Velde, B. (1992) Introduction to Clay Minerals: Chemistry, Origins, Uses and Environmental Significance. Chapman and Hall, London, 1-17, 55-82, 96. https://doi.org/10.1007/978-94-011-2368-6

[30] Fahrenholtz, W.G. (2008) Clays. In: Shackelford, J.F. and Doremus, R.H., Eds., Ceramic and Glass Materials: Structure, Properties and Processing, Springer, New York, 111-133. https://doi.org/10.1007/978-0-387-73362-3_7

[31] Kaolinite in Wikipedia (2015). https://en.wikipedia.org/w/index.php?title=Kaoliniteandoldid=693335566

[32] Duval, D.J., Risbud, S.H. and Shackelford, J.F. (2008) Mullite. In: Shackelford, J.F. and Doremus, R.H., Eds., Ceramic and Glass Materials. Structure, Properties and Processing, Springer, New York, 27-39. https://doi.org/10.1007/978-0-387-73362-3_2

[33] Lamberov, A.A., Sitnikova, E.Yu. and Abdulga, A.Sh. (2012) Kinetic Features of Phase Transformation of Kaolinite into Metakaolinite for Kaolin Clays from Different Deposits. Russian Journal of Applied Chemistry, 85, 892-897. https://doi.org/10.1134/S1070427212060109

[34] Ghosh, A. and Ghosh, S. (2014) A Textbook of Metallurgical Kinetics. PHI Learning Private Ltd., Delhi, 1-10, 82-100, 151-185, 301-319.

[35] Gupta, C.K. (2003) Chemical Metallurgy: Principles and Practice. Wiley-VCH Verlag GmbH and Co., Weinheim, 31-52, 459-499. https://doi.org/10.1002/3527602003

[36] Rao, S.R.R. (2006) Hydrometallurgical Processes. In: Resource Recovery and Recycling from Metallurgical Wastes, Waste Management Series, Volume 7, Chapter 4, Elsevier Science, Oxford, 71-108.

[37] Brown, T.L., LeMay, H.E.Jr., Bursten, B.E., Murphy, C.J. and Woodward, P.M. 
(2012) Chemistry: The Central Science. 12th Edition, Pearson Education, Inc., New York, 512-655.

[38] Al-Zahrani, A.A. and Abdul-Majid, M.H. (2009) Extraction of Alumina from Local Clays by Hydrochloric Acid Process. Engineering Science Journal of King Abdulaziz University, Saudi Arabia, 20, 29-41. https://doi.org/10.4197/Eng.20-2.2

[39] Al-Ajeel, A.W.A. and Al-Sindy, S.I. (2006) Alumina Recovery from Iraqi Kaolinitic Clay by Hydrochloric Acid Route. Iraqi Bulletin of Geology and Mining, 2, 67-76.

[40] Ajemba, R.O. and Onukwuli, O.D. (2012) Determination of the Optimum Dissolution Conditions of Ukpor Clay in Hydrochloric Acid Using Response Surface Methodology. International Journal of Engineering Research and Applications, 2, 732-742.

[41] Udeigwe, U., Onukwuli, O.D., Ajemba, R. and Ude, C.N. (2015) Kinetic Studies of Hydrochloric Acid Leaching of Alumina from Agbaja Clay. International Journal of Research in Advanced Engineering and Technology, 1, 64-72. 